\title{
THE CLOSED-LOOP ECONOMY
}

\author{
RICHARD G. CARRANZA \\ Chemical Engineering Consultant, Montgomery, Texas, USA.
}

\begin{abstract}
The economy is modeled as an engineering pumping system. At the start, no control is used; thus, the open-loop system is established. Flow, or analogously GDP, is sent from a pump to a storage tank (analogously, inventories). Control is then applied where investment (flow out of the tank) is controlled via the interest rate. Thus, the open loop becomes a closed loop. It is shown from simple example that frequent government interference in the economy causes more instability than less government interference. Dynamic systems tend toward steady-state systems and government interference should be very selective and careful. In this work, the interest rate is used to control the economy by the Federal Reserve, ceteris paribus. Simulations indicate that when the Fed attempts to control the economy using interest rates, the net effect is that economic equilibrium is delayed with respect to an economy that comes to equilibrium naturally.
\end{abstract}

Keywords: consumption, control, economics, feedback, investment, loop, macroeconomics, savings.

\section{INTRODUCTION}

The similarities between economics and biology are striking. Symbiotic relationships prevail everywhere in nature. Yet, the goal of the scientist is to pull this apparently disjointed universe into a coherent logical system. This work makes an attempt to do this for a dynamic macroeconomic system.

The theory of evolution asserts that, between 3 to 4 billion years ago, the atmosphere of the earth is primarily hydrogen, water, ammonia, and methane [1]. Energy obtained from sunlight and lighting then turn these simple molecules into complex structures such as carboxylic acids, amino acids, and other organic molecules. Ultimately, proteins, nucleic acids and polysaccharides follow in sequence. Inorganic elements, like phosphorus and sulfur, in the earth also help to create more complex organic materials.

Since proteins, which are made from amino acids, are polar molecules; the polar regions of the protein are attracted to the polar sides of water molecules. As proteins aggregate in this way, a type of membrane is formed. Another theory proposes that membranes are formed via lipids. Lipids are not soluble in water and easily form membranes two molecules thick. Nucleic acids slip past the membrane and life is formed.

As photosynthesis is introduced, oxygen fills the earth's atmosphere, and the first cells are classified into several categories. Autotrophs are cells that use photosynthesis for energy (the fuel source is inorganic), both aerobic and anaerobic. Heterotrophs, aerobic and anaerobic, are cells that do not use photosynthesis - they use organic matter for energy.

Evolutionary theory suggests that anerobic heterotrophs begin to absorb aerobic heterotrophs; and that both benefit because the anaerobic cell acquires the organic food for the aerobic cell, while on the other hand the aerobic cell produces energy more efficiently - energy that is shared with the 
anaerobic cell. A symbiotic relationship is formed. The aerobic cell evolves into what is now known as the mitochondria.

The heterotrophs that contain mitochondria now start to absorb autotrophs. The autotrophs evolve into chloroplast. This is the foundation of plant life.

The earth, at this stage, is starting to exhibit signs of the specialization of labor. The theory of evolution teaches that cells begin to specialize in such things as leaves, roots, branches, etc. The symbiotic relationship is continuing within the plant kingdom: the cells that specialize in forming leaves help to maintain the cells that become roots and branches - and vice versa. The specialization of labor continues in the animal kingdom too. Cells start to form hearts, brains, kidneys, livers, etc.

Specialization of labor is nature's way of struggling to survive. So far in this discussion, cells cooperate to survive. Those cells that survive until they can replicate, pass on their genetic information to the next generation. Darwin calls this the survival of the fittest.

The sociologist Herbert Spencer extends this thought further. He claims that human society is rooted in the natural tendency of cellular survival. This is done by humans forming many tribes, ethnicities, cities, and countries. Specialization of labor is continuing in the form of the different branches of government and the diversity of businesses. Labor is specialized in terms of law, engineering, politics, education, construction, medicine, etc. Spencer draws analogies between specialized branches of government and human organs. He compares highways and rail lines to arteries. Ultimately, he claims that money is the lifeblood of human existence: money is what sends nutrition to all parts of the body.

Here is Spencer in his own words, "The circulating mass of nutritive materials in individual organisms and in social organisms, becoming at once better in the quality of its ingredients and more heterogeneous in composition, as the type of structure becomes higher, eventually has added to it in both cases another element, which is not itself nutritive but facilitates the processes of nutrition. We refer, in the case of the individual organism, to the blood-discs; and in the case of the social organism, to money. This analogy has been observed by Liebig, who in his Familiar Letters on Chemistry says:

'Silver and gold have to perform in the organism of the state, the same function as the bloodcorpuscles in the human organism. As these round discs, without themselves taking an immediate share in the nutritive process, are the medium, the essential condition of the change of matter, of the production of the heat and of the force by which the temperature of the body is kept up, and the motions of the blood and all the juices are determined, so has gold become the medium of all activity in the life of the state.'

And blood-corpuscles being like coin in their functions, and in the fact that they are not consumed in nutrition, he further points out that the number of them which in a considerable interval flows through the great centers, is enormous when compared with their absolute number; just as the quantity of money which annually passes through the great mercantile centers, is enormous when compared with the quantity of money in the kingdom. Nor is this all. Liebig has omitted the significant circumstance that only at a certain stage of organization does this element of the circulation make its appearance. Throughout extensive divisions of the lower animals, the blood contains no corpuscles; and in societies of low civilization, there is no money." [2]

Spencer now brings the discussion full circle: a model for the behavior of a complex economic system. This discussion hints that the political economy is simply one more step in cellular evolution. Nevertheless, the microscopic enzymatic reactions that occur within cell walls are modeled using a macroscopic equation called the Michaelis-Menten equation. Analogously, the economy is modeled using macroscopic equations too, for instance aggregate demand. Aggregate demand is simply the summation of all the little demands that originate from all the individual human organisms in the society. 


\section{TERMS AND DEFINITIONS}

The linguistic philosopher, Ludwig Wittgenstein, asserts that language is a game with rules and that confusion occurs when people do not stick to the rules: "It is the philosophers, of course, according to Wittgenstein in Philosophical Investigations, who persist to misusing language. The problems of philosophy are only linguistic problems, word puzzles which trap philosophers because they do not follow the rules of the ordinary English language game. Philosophers mistakenly look for the essence of words; they mistakenly construct ideal languages and criteria of meaning from the features of a few examples, as if such languages were more perfect than everyday langauge; they mistakenly try, as Plato and Hegel did, to synthesize all human experience and knowledge, but this, according to Wittgenstein, is total confusion, a mixing up of many different language games - art, religion, science, ethics, politics - into one nonsensical hodgepodge. Philosophers' problems are not genuine problems but only the nonsense that results from not knowing how to handle language." [3] Therefore, a few important definitions are established before proceeding.

Complex systems, definitively, are "open" - that is, the system has exchange with the environment. The closed-loop economy here does not refer to material nor energy exchange with the environment. On the contrary, raw materials come into the economy and leave as goods and services. Rather, the word closed refers to signal processing.

The terms "open" and "closed" are used in the context of traditional engineering control theory. For instance, assume you have a pot of water that you wish to heat to $100^{\circ} \mathrm{F}$. If one simply places the pot on a gas burner and walks away, the temperature reaches $212^{\circ} \mathrm{F}$; because there is no feedback to a "controller" that adjusts the amount of heat supplied such that the temperature of the water stays at $100^{\circ} \mathrm{F}$. This is called an open-loop system - no feedback.

If a visiable temperature guage is placed in the water, and one stands at the burner and stops the flow of gas when the temperature is $100^{\circ} \mathrm{F}$, feedback is established and this is called a closed loop. In other words, the individual provides a set point temperature. The thermometer provides a sample of the real temperature in the water. The individual, or the controller, makes a comparison between the set point and the actual temperatures, and adjusts the system such that the objective temperature is reached. The system comes around full circle with a process of adjustment, measurement, comparison, adjustment, etc. - a closed loop. Typically, automatic control is applied with electronics: thermocouples, controllers, actuated control valves, and other such devices.

\section{OPEN-LOOP ECONOMY}

A detailed analysis of the open-loop economy is given by Carranza [4]. However, a short review is given here. Figure 1 is an example of an open-loop economy as given by Carranza [4]. The ratios of mps to mpc are natural elements of the economy. Thus, in Fig. 1, the ratios are maintained by the natural flow mechanics of the system. Note that there is no friction in the system.

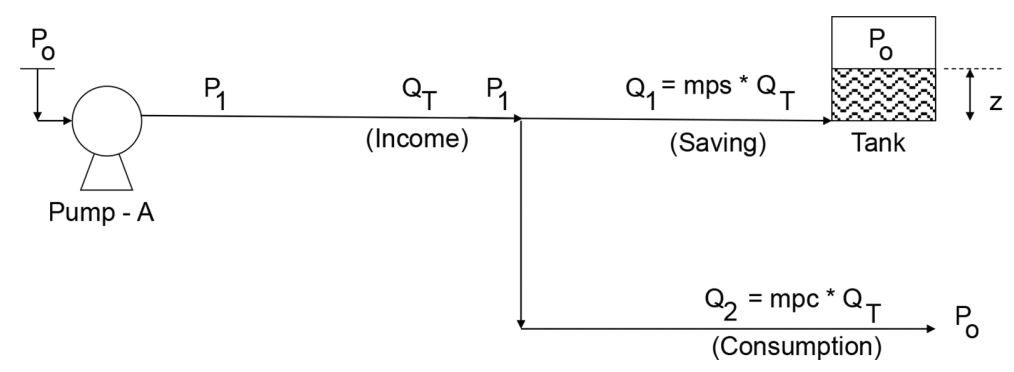

Figure 1: Basic open-loop economy. 


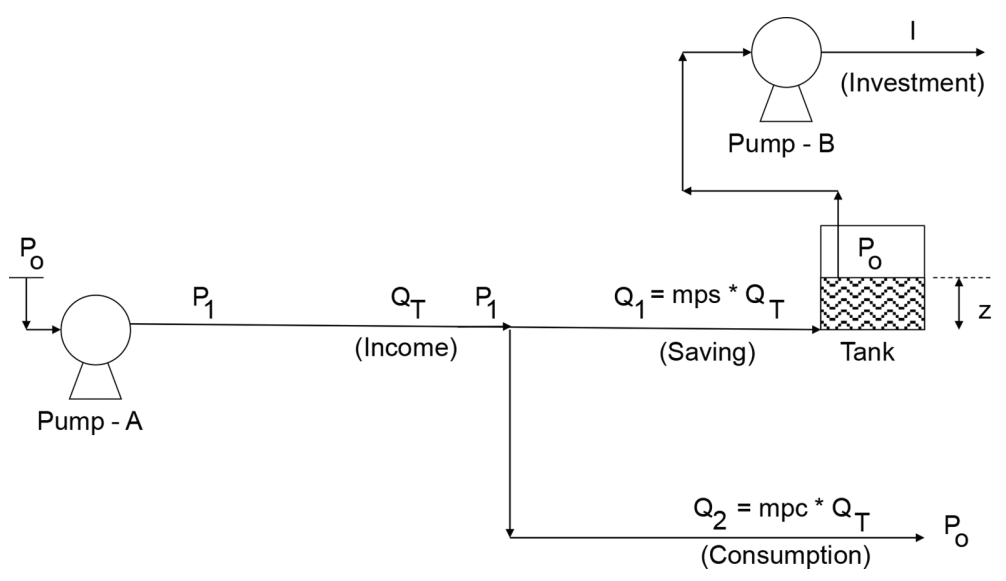

Figure 2: Open-loop economy with investment.

Figure 2 is the same system but this time pump B is added to the tank. This outflow is called investment. In economics, this is more accurately called net investment because some investment is saved as inventories. The saved inventories are represented by the liquid level in the tank.

From Bernoulli's equation, pump A discharge pressure is given as the following simple relationship (no friction, no velocity effects):

$$
\frac{P_{1}}{\rho g}=\frac{P_{o}}{\rho g}+z
$$

It must be remembered that eqn (1) is a steady-state equation. It must be converted to a dynamic equation. This is done by adding an infinitesimally small step change to the right hand side of eqn (1). The step change takes into account the amount of liquid that enters the tank for each time interval:

$$
\Delta z=\frac{\left(Q_{1}-I\right) \Delta t}{A}
$$

Note the following important relationships: $\mathrm{mps}+\mathrm{mpc}=1.0, \mathrm{I}=0.1 \mathrm{~m}^{3} / \mathrm{s}, \mathrm{A}=0.2 \mathrm{~m}^{2}, \Delta \mathrm{t}=0.01 \mathrm{~s}$, $\mathrm{mps}=0.2$. Also note the following important eqns (observe that the pressure across pump $\mathrm{A}$ is essentially the height of the liquid in the tank, since there is no friction):

$$
\begin{gathered}
\Delta P=P_{1}-P_{o}=\rho g h_{p} \\
Q_{1}=\text { mps } Q_{T} \\
h_{p}=-Q_{T}^{2}+1 \Rightarrow \text { pumpcurve }
\end{gathered}
$$

When eqns (1)-(5) are all combined, a quadratic polynomial is the result. The polynomial is then solved using the quadratic equation. The final solution is given in eqn (6). Equation (6) gives the flow through pump A for each time interval.

$$
Q_{T, t+1}=\frac{\Delta t-\sqrt{\Delta t^{2}+4\left(1-z_{t}+5 I \Delta t\right)}}{-2}
$$


It can also be shown that the level in the tank is given by eqn (7).

$$
z_{t+1}=z_{t}+\frac{\left(m p s Q_{T, t+1}-I\right) \Delta t}{A}
$$

Equations (6) and (7) are plotted in Fig. 3 when $I=0$, no investment. The way the hydraulics network is set up, the inventories in the tank bring the system to a near halt. Analogously, rising inventories slow down an economy. Without government intervention, each individual shop owner in the economy simply looks at his inventory room and curbs production as inventories start to rise. The result is a drop in GDP and unemployment. It is important to point out here that $\mathrm{Q}_{\mathrm{T}}$ is analogous to real GDP, which is equal to $\mathrm{C}+\mathrm{I}$ since at present government spending and net exports are neglected. Savings is equal to I, net investment plus inventories.

Investment is added to the economy and represented in Fig. 4. Investment is fixed at $0.1 \mathrm{~m}^{3} / \mathrm{s}$. Such being the case, the economy naturally comes to equilibrium when the total flow or real GDP is equal
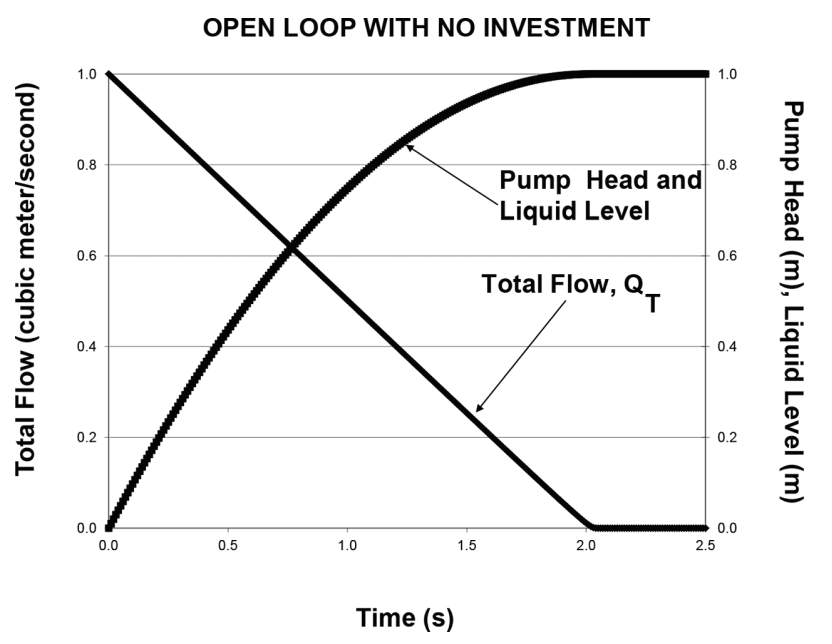

Figure 3: Open-loop economy with no investment.

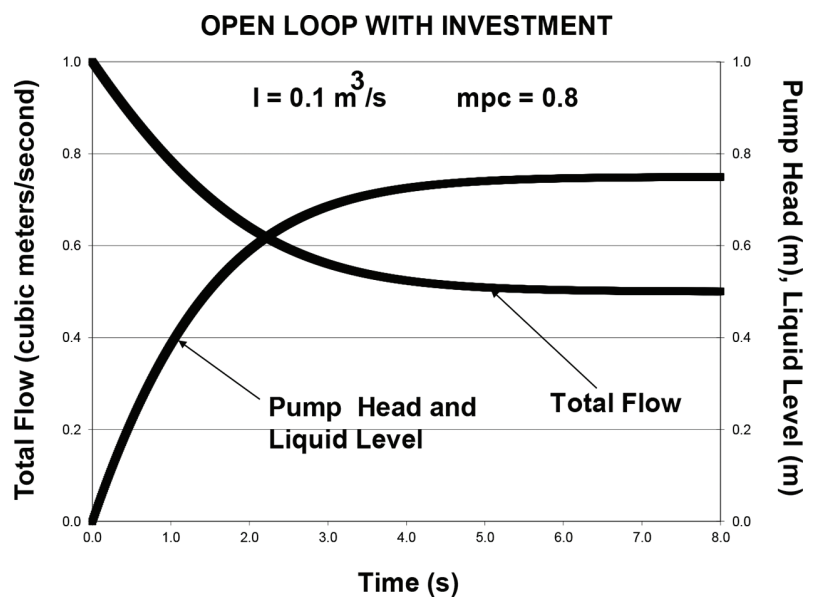

Figure 4: Open-loop economy with investment. 
to $0.5 \mathrm{~m}^{3} / \mathrm{s}$. In other words, the rising inventory in the tank naturally forces the pump to flow less liquid. Analogously, the economy responds to rising inventories and generates less product. Liquid level and consumption are $0.75 \mathrm{~m}$ and $0.4 \mathrm{~m}^{3} / \mathrm{s}$, respectively. Note that consumption plus investment equals total GDP at equilibrium. Furthermore, since inventories are not accumulating, $\mathrm{S}=\mathrm{I}$.

\section{CLOSED-LOOP ECONOMY}

The close-loop economy is exemplified in Fig. 5. The level transmitter controller (LTC), represents the Federal Reserve System. Pump B drives investment and is operated by a variable speed motor. The motor is controlled by the Fed via the discount window interest rate.

A typical scenario in which the Fed attempts to bring "stability" to the economy is by closely watching the nation's inventory levels. The Fed knows that if inventories rise, then the economy starts to slow - as is shown in Fig. 3. Thus, the Fed sets an inventory target and controls investment with interest rates. In classical economics, investment and interest rates are negatively correlated; therefore, they are here defined by the following relationship, for the sake of simplicity: $\mathrm{I}=1 / \mathrm{i}$.

The simulation in Fig. 4 is rerun, but this time the Fed controls investment. Note that in Fig. 5 a feedback loop is established - the liquid level is observed by the LTC or the Fed, the liquid level is compared to the target level (otherwise known as the set point), interest rate is adjusted, the rate of investment is altered, the liquid level changes and again is compared to the set point, ad infinitum.

In Fig. 4, one observes that the economy naturally comes to rest when the liquid level is $0.75 \mathrm{~m}$. With the Fed involved in Fig. 5, the inventory target that is set by the Fed is $0.75 \mathrm{~m}$ also. Equations 5 and 6 are utilized again but with the following initial specifications at $\mathrm{t}=0.0: \Delta \mathrm{t}=0.01 \mathrm{~s}, \mathrm{i}=10 \%$, liquid level $=0.0 \mathrm{~m}$, set point $=0.75 \mathrm{~m}$. Since there is no liquid level pushing back on Pump A, initially, the pump operates at full capacity, $1.0 \mathrm{~m}^{3} / \mathrm{s}$.

Using the above information, the first simulation of four involves the Fed adjusting the interest rate at every time interval. If the inventory level is below the set point, the Fed raises interest rates by $0.1 \%$. This rise in interest rates slows investment and allows inventory to build in the tank. Likewise, if the inventory level is above the set point then the Fed will lower interest rates by $0.1 \%$. The results of simulation 1 are given in Fig. 6.

In simulation 2, everything is kept the same except the set point. The new set point is $0.5 \mathrm{~m}$. The results are given in Fig. 7. In both simulations 1 and 2, one overarching conclusion is made. The

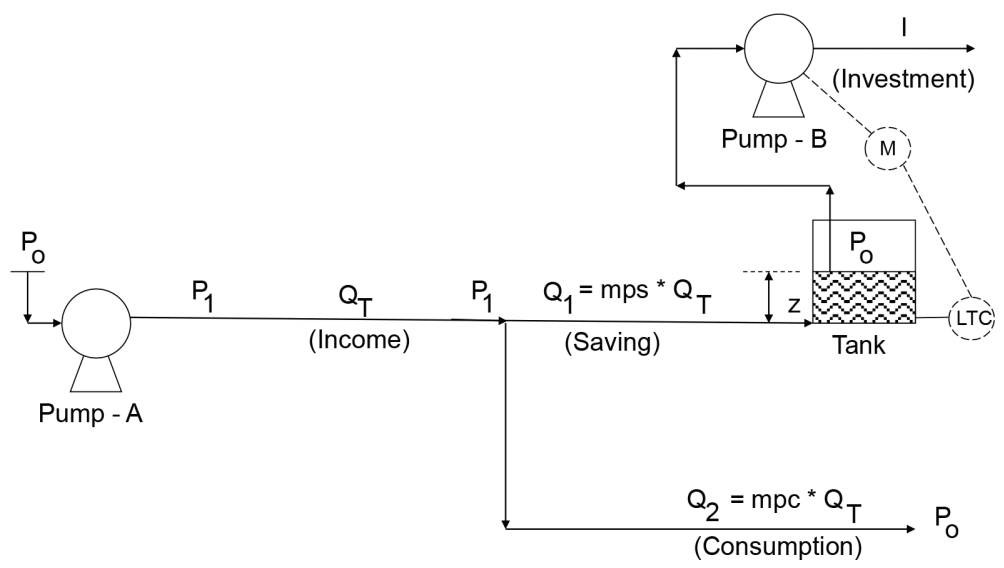

Figure 5: Closed-loop economy. 


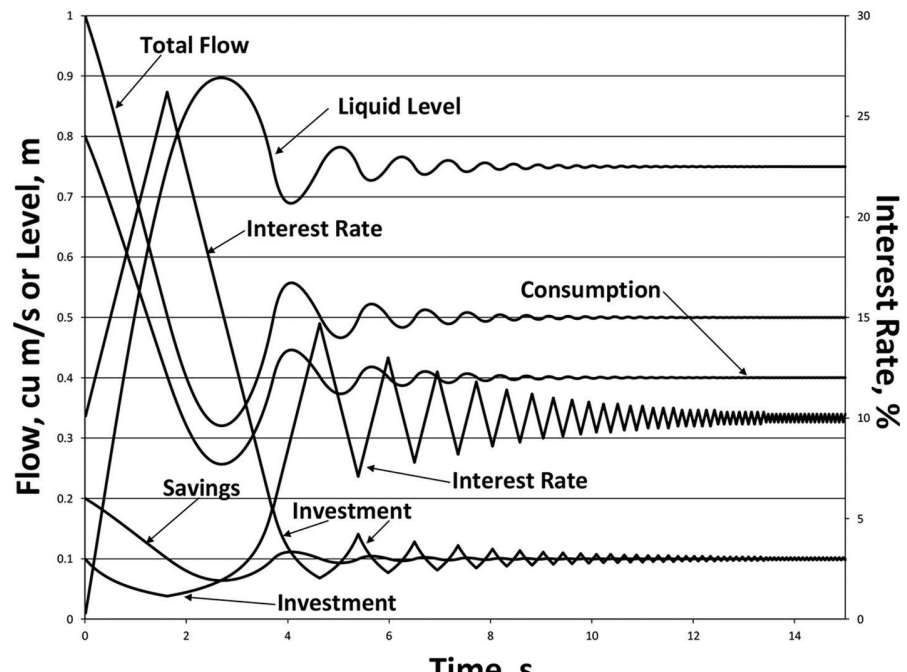

Time, $s$

Figure 6: Simulation 1.

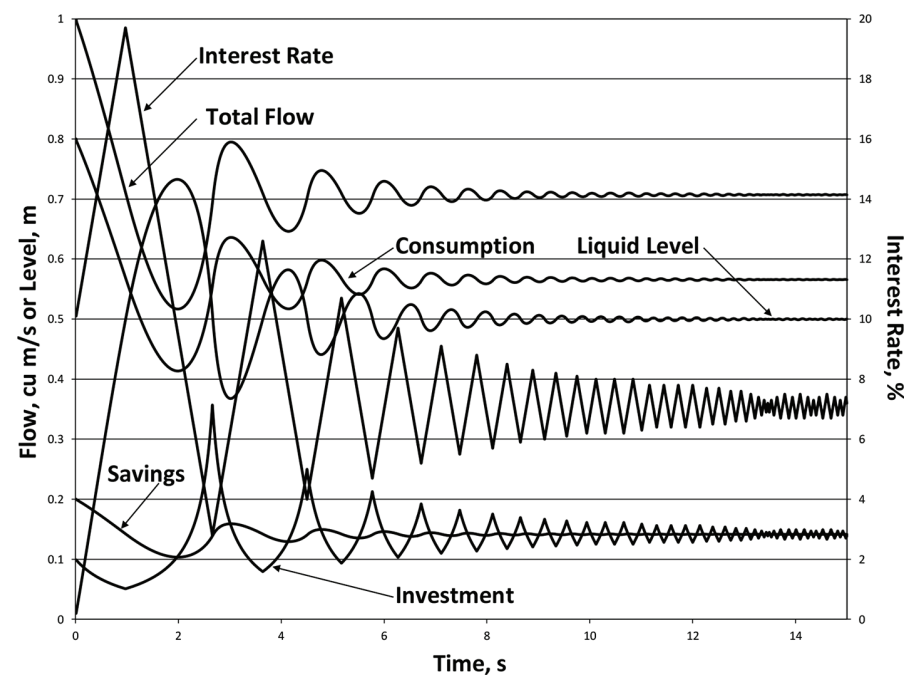

Figure 7: Simulation 2.

system is in complete chaos. It is barely being kept in control. Another way to say this is poor control loop tuning.

Simulation 3 is the same as simulation 1 but with a single difference: the Fed does not respond as fast, this time the Fed changes interest rates with every set of 10 time intervals - otherwise known as dead time, see Fig. 8.

Simulation 4 is the same as simulation 3 but with a different set point: inventories $=0.5 \mathrm{~m}$, see Fig. 9. Observing both simulations 3 and 4, an interesting observation is made - less Fed involvement makes for a better economy. 


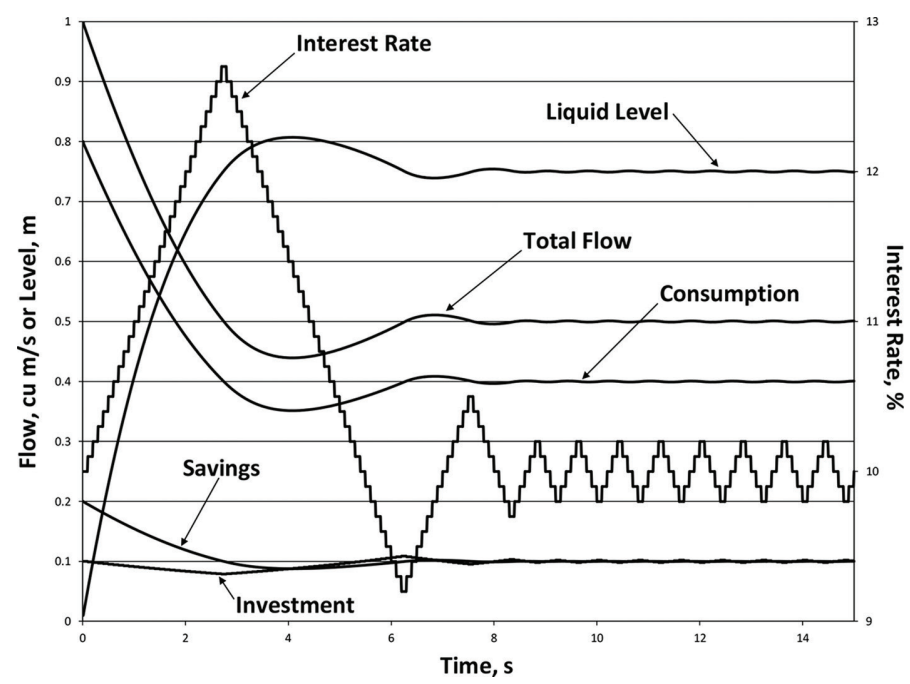

Figure 8: Simulation 3.

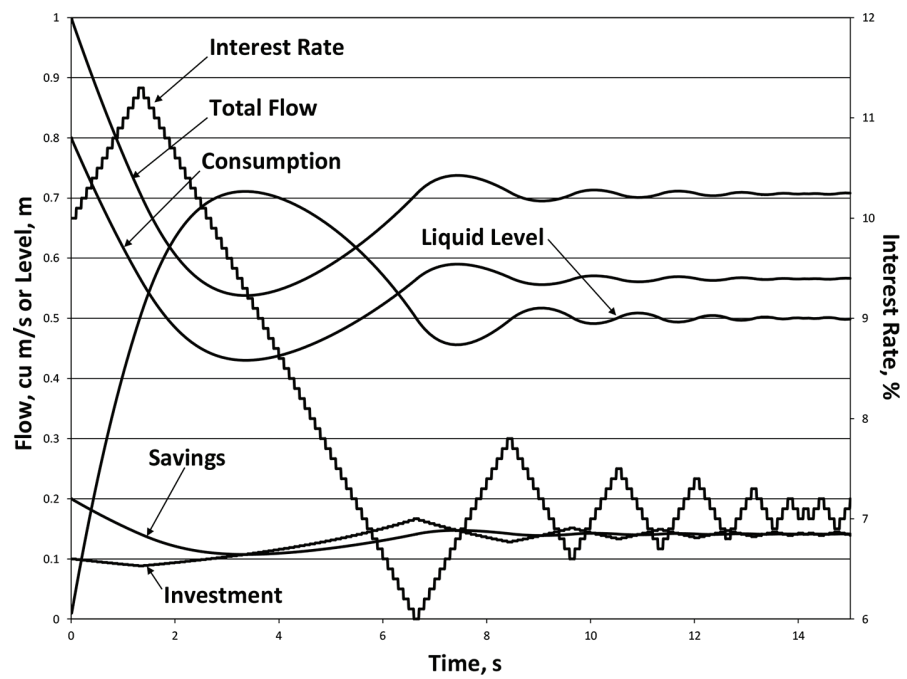

Figure 9: Simulation 4.

\section{RESULTS AND CONCLUSIONS}

As is shown in Figs 8 and 9, less government involvement in the economy is highly desirable. Most schools of economic thought springing forth after the time of Keynesian economics state the same principle.

"Unlike Keynesian economists, monetarists do not believe that the economy is subject to a disequilibrium that must be offset by government action. Most monetarists believe that the economy tends toward equilibrium at the level of potential national income. Their faith in the free market (price) system leads them to favor minimal government intervention ... Monetarists often argue that government policy heightens the effects of the business cycle . . Monetarist favor non-activist 
government policy because they believe that the government's attempt to make the economy better off by aiming monetary and fiscal policies at low inflation and low unemployment often make things worse." [5]

The results of this work definitely support the monetarists in their point of view. Other schools of thought that believe in minimum government involvement include new classical economics and rational expectations.

By looking at the historical data for the discount window interest rate, one sees the hopelessness of government intervention in the economy. Between 2005 and 2008, Fed chairmen Greenspan and Bernanke both raise interest rates to "cool off" the economy, but the reality is that the economy is torpedoed by sending countless adjustable rate mortgages into default. Since 2008, the Fed tries to "revive" the economy with low interest rates, with no avail.

In conclusion, human activity, past and future, is very much a function of human genetics. There is room for reason, but in conjunction with sound judgment. In the words of Ilya Prigogine, "Economic systems are also unstable, 'chaotic' systems.... we have to expect instability in social systems as decisions are no longer associated with some deterministic rule."

"The decision-making process introduces an essential difference between physical and social systems. ... No longer is there a gap between the 'hard' sciences speaking of certitudes and the 'soft' sciences dealing with possibilities."

"... the universe is ruled both by laws and by events . . . Therefore, we have choices, we have values. It goes far beyond the competence of a physicist to describe the origin and variety of human values. My more modest role has been to emphasize that the existence of values, and therefore also of economic values, is in line with our present description of the physical universe." [6]

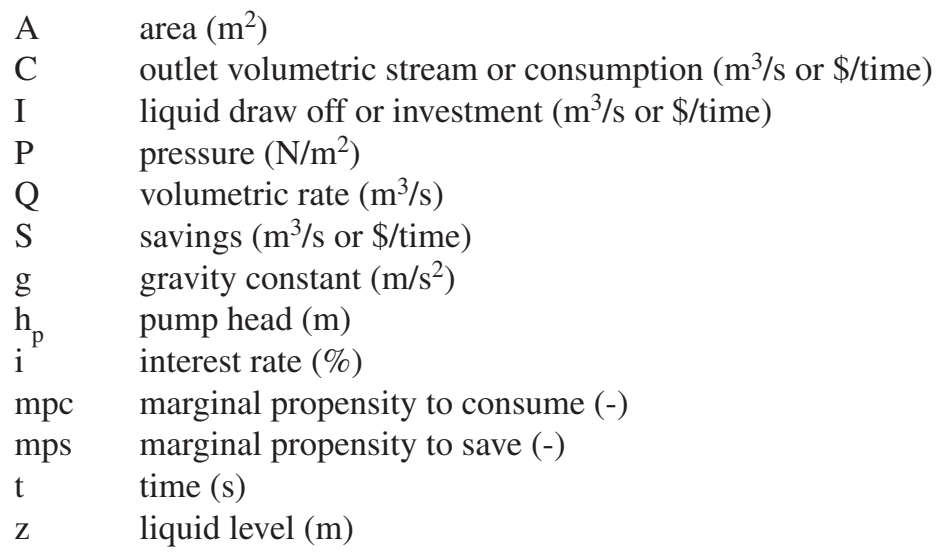

GREEK LETTERS

\begin{tabular}{|c|c|c|}
\hline$\Delta$ & $\begin{array}{l}\text { change } \\
\text { density }\left(\mathrm{kg} / \mathrm{m}^{3}\right)\end{array}$ & \\
\hline & & SUBSCRIPTS \\
\hline $\mathrm{T}$ & total & \\
\hline & atmospheric con & ime condition \\
\hline & time & \\
\hline
\end{tabular}




\section{REFERENCES}

[1] Wolfe, S.L. \& Miller, G.T., Biology: The Foundations, Wadsworth Publishing Company: Belmont, California, 1977.

[2] Spencer, H., The Social Organism, The Westminster Review, 1860.

[3] Lavine, T.Z., From Socrates to Sartre: The Philosophic Quest, Bantam Books: New York, 1984.

[4] Carranza, R., The open loop economy. The Business Review, Cambridge, 6(2), 2008.

[5] Boyes, W. \& Melvin, M., Economics, Houghton Mifflin Co: Boston, 1991.

[6] Prigogine, I., The rediscovery of value and the opening of economics (Chapter 2). The Evolutionary Foundations of Economics, ed. K. Dopfer, Cambridge University Press: Cambridge, 2005. 